DOI: 10.32347/2412-9933.2020.44.56-64

УДК 539.3

\title{
Lizunov Petro
}

DSc(Eng.), Professor, Head of Department of Computer Sciences, orcid.org/0000-0003-2924-3025

Kyiv National University of Construction and Architecture, Kyiv

Nedin Valentyn

Assistant of professor, Department of Computer Sciences, orcid.org/0000-0003-3138-2892

Kyiv National University of Construction and Architecture, Kyiv

\section{THE PARAMETRIC OSCILLATIONS OF ROTATING ELASTIC RODS UNDER THE ACTION OF THE PERIODIC AXIAL FORCES}

\begin{abstract}
The paper presents the results of numerical investigation of the periodic axial forces' influence on the transverse oscillations of long rotating rods. The gyroscopic inertia forces are taken to account and space oscillating process of rotating rods is considered with account of geometric nonlinearity. The study has been done with computer program with a graphical interface that is developed by authors. The process of numerical solution of the differential equations of oscillations of rotating rods using the method of numerical differentiation of rod's bend forms by polynomial spline-functions and the Houbolt time integration method is described. A general block diagram of the algorithm is shown. This algorithm describes the process of repeated (cyclical) solving of the system of differential equations of oscillations for every point of mechanical system in order to find the new coordinates of the positions of these points in each next point of time $t+\Delta t$. The computer program in which the shown algorithm is realized allows to monitor for the behavior of moving computer model, which demonstrates the process of oscillatory motion in rotation. Moreover, the program draws the graphics of oscillations and changes of angular speeds and accelerations in different coordinate systems. Using this program, the dynamics of a range of objects which are modeled by long elastic rods have been studied. For investigated objects is shown that on various rotational speeds and beat frequencies the oscillatory motion of the rods occurs with different character of behavior. On certain speeds with different frequencies of axial load the oscillations have definite periodicity and occur with beats of amplitude which are the result of the periodic axial force action.
\end{abstract}

Keywords: rotating rods; transverse oscillations; numerical differentiation; gyroscopic forces; axial forces

\section{Introduction}

The tasks of stress-deformed state and oscillations of elastic rotating rods have actuality while structural elements of machines and devices are designed. The rotating rods are responsible elements in the constructions of engines, turbines, drill strings, hammer drills and other machines. For these objects the cause of the development of oscillations can be both inertial forces and periodic external forces, such as axial forces.

For example, during the operation of drill string the influence of bottom hole reaction can be periodical as a result of its transverse oscillations, at which the axial moving of its movable end occurs. During the operation of industrial hammer drill the action on the drill is periodic too.

When the rod rotates and begins to bend under the action of external forces, the gyroscopic inertia forces start to transmit the energy of system in a direction that is perpendicular to the plane of bending. After it the rod begins to oscillate in two mutually perpendicular planes of the coordinate system that rotates with it.
The behavior of rotating elastic rods systems is described by complex differential equations with partial derivatives with account of gyroscopic inertia forces. Low rigidity, large length, relatively high values of the excitation intensity parameters, in which the structural elements are used, all of these make the necessary to analysis of oscillatory motion around of critical and overcritical rotational speeds. Also, these make the necessary to search the natural oscillation frequencies range and range of critical rotational speeds with account of gyroscopic forces, and stability analysis in the study of different motion modes.

The analysis of presented in scientific literature results shows that the task of investigation of dynamics and strength of rotating elastic systems, with account of gyroscopic forces and axial loads, is actual. Many authors are paid attention to calculation of critical rotational speeds and natural oscillation frequencies by different system parameters. But the nature of the oscillation process itself and how the certain parameters of the system influence on the development of oscillations almost is not considered. Therefore, it is interesting to 
study the dynamic behavior of the consider systems and define what kind of effects the gyroscopic forces and periodic axial forces generate.

\section{The article purpose}

Purpose - to demonstrate the results of a numerical study of the oscillatory motion of rotating rods with account of gyroscopic and axial forces, also to show what influence and how these forces have on the transverse oscillations of the rods during rotation.

\section{Main material}

\section{Problem statement}

In the process of oscillation of rotating rods with considerable lengths, under the action of external periodic forces and gyroscopic inertia forces, the various bend forms that change in time are possible. Beside this, the various character of the oscillatory motion itself for different physical, geometric and dynamic parameters are possible too.

As a dynamic model is considered a rod with length $l$ (Fig. 1) that is under the action of periodic axial force $P(t)$. The rod rotates on angular speed $\omega$ around the rectilinear axis $O_{1} X_{1}$ of the stationary coordinate system $O_{1} X_{1} Y_{1} Z_{1}$. The rotating coordinate system $O X Y Z$ is tied to the rod and rotates with it. The direction of $O X$ axis coincides with direction of $O_{1} X_{1}$ axis. Axis of rod in deformed state is coincided with the $O X$ and $O_{1} X_{1}$ axis. The oscillatory motion of the rod in the $O X Y Z$ coordinate system is characterized by $y(x, t)$ and $z(x, t)$ displacements of the points, that belong to the axis of rod in the $O Y$ and $O Z$ coordinate axes' direction, respectively.

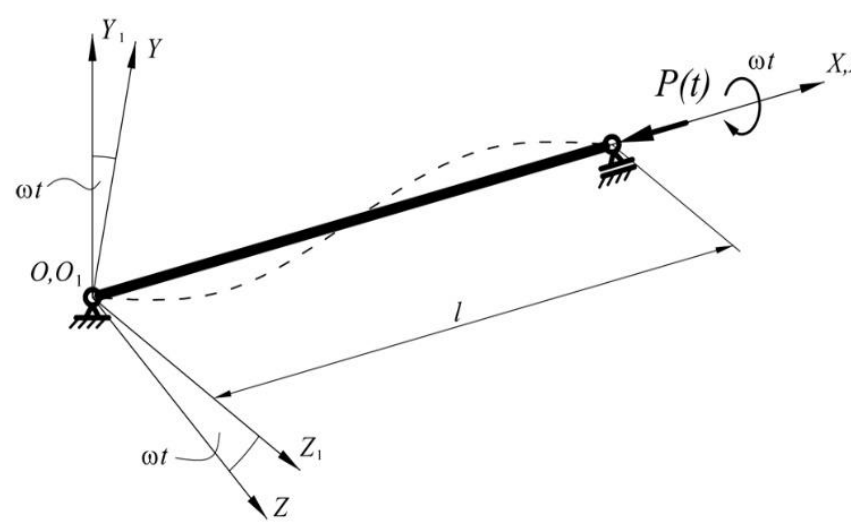

Figure 1 - Dynamic model of system.

The oscillations of rotating rod in space are described by the corresponding system of differential equations, which taking into account the geometric nonlinearity, gyroscopic forces and the axial periodic force $[2,3]$ have a form:

$$
\left\{\begin{array}{l}
\frac{d^{2}}{d x^{2}}\left(\frac{E I_{1(x)}}{\rho_{1}}\right)-\bar{m} r^{2}\left(\frac{d^{4} y}{d t^{2} d x^{2}}+\omega^{2} \frac{d^{2} y}{d x^{2}}\right)-2 \omega \bar{m} \frac{d z}{d t}- \\
-\bar{m} \omega^{2} y+\bar{m} \frac{d^{2} y}{d t^{2}}+P(t) \frac{d^{2} y}{d x^{2}}=0 \\
\frac{d^{2}}{d x^{2}}\left(\frac{E I_{2}(x)}{\rho_{2}}\right)-\bar{m} r^{2}\left(\frac{d^{4} z}{d t^{2} d x^{2}}+\omega^{2} \frac{d^{2} z}{d x^{2}}\right)+2 \omega \bar{m} \frac{d y}{d t}- \\
-\bar{m} \omega^{2} z+\bar{m} \frac{d^{2} z}{d t^{2}}+P(t) \frac{d^{2} z}{d x^{2}}=0,
\end{array}\right.
$$

where $E$ - elastic modulus of rod's material; $I_{1}, I_{2}-$ inertia moments of rod section in mutually perpendicular planes; $r$ - radius of gyration; $\bar{m}$-mass of unit per length; $\omega$ - rotational speed of rod around the axis that coincides with the axis of rod in undeformed state; $P(t)$ periodic axial force; $1 / \rho_{1}, 1 / \rho_{2}-$ main curvatures of rod's axis in mutually perpendicular planes.

The action of axial periodic force is modeled by function, that looks like as: $P(t)=P_{\max }\left(a^{1+\cos \theta t}-a^{2}\right)$.

\section{Technique}

The solving of differential equations of rotating rods oscillations for searching of their geometric position in space in the process of oscillation and analysis of dynamic behavior is carried out using the method of numerical differentiation described in papers [7, 8], and the Houbolt time integration method [10] in form:

$$
\begin{aligned}
& \ddot{y}_{n}^{t+\Delta t}=\frac{1}{\Delta t^{2}}\left[2 y_{n}^{t+\Delta t}-5 y_{n}^{t}+4 y_{n}^{t-\Delta t}-y_{n}^{t-2 \Delta t}\right] \\
& \dot{y}_{n}^{t+\Delta t}=\frac{1}{6 \Delta t}\left[11 y_{n}^{t+\Delta t}-18 y_{n}^{t}+9 y_{n}^{t-\Delta t}-2 y_{n}^{t-2 \Delta t}\right] \\
& \ddot{z}_{n}^{t+\Delta t}=\frac{1}{\Delta t^{2}}\left[2 z_{n}^{t+\Delta t}-5 z_{n}^{t}+4 z_{n}^{t-\Delta t}-z_{n}^{t-2 \Delta t}\right] \\
& \dot{z}_{n}^{t+\Delta t}=\frac{1}{6 \Delta t}\left[11 z_{n}^{t+\Delta t}-18 z_{n}^{t}+9 z_{n}^{t-\Delta t}-2 z_{n}^{t-2 \Delta t}\right]
\end{aligned}
$$

Such solution executes in order to find the coordinates $y_{n}^{t+\Delta t}, z_{n}^{t+\Delta t}$ of rod axis for next point of time $t+\Delta t$ (Fig. 2).

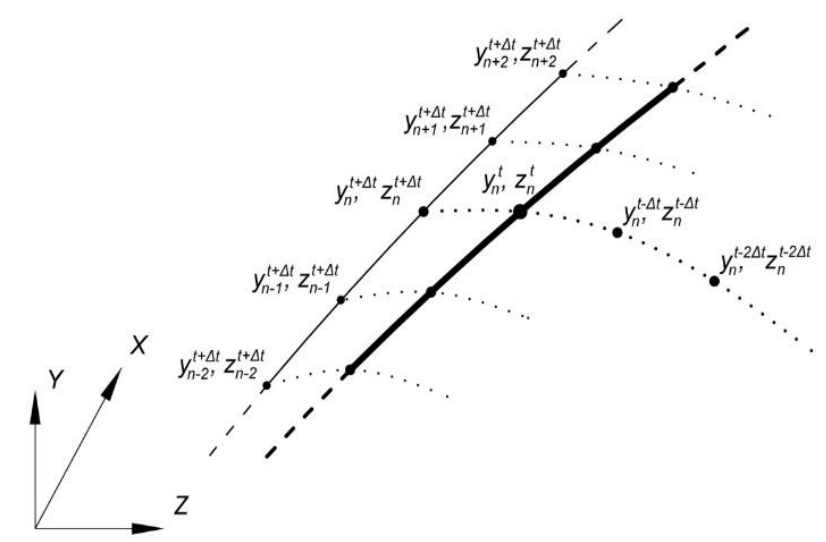

Figure 2 -Rod's motion trajectory 
The solving of the dynamic tasks of the oscillatory motion for rotating rods, based on described technique, has been done with computer program with a graphical interface. The general block diagram's algorithm of the program is shown in Figure 3.

This algorithm describes the process of repeated (cyclical) solving the system of differential equations of oscillations for every point of rod elastic line in order to find the new coordinates for these points in each next point of time $t+\Delta t$. This is performed with the show of current calculations' results as a moving computer model, which displays the oscillating process of rotating rod in real time.

\section{Results}

Using specified program, the dynamics of objects which are modeled by long elastic rods have been studied. In this way for steel rod with diameter $d=12 \mathrm{~mm}$ and length $l=1 \mathrm{~m}$ during rotation with different rotational speeds $\omega$ under action of axial beat load with different frequencies $\theta$ the oscillations diagrams are shown below at figures 4-7.

For this rod the graphics of oscillations while rotating on critical speed of the 1-st harmonic that is equal to $145.5 \mathrm{~s}^{-1}$, but without action of external axial force, are shown at figure 4 . As we can see, the transverse oscillations in the rotating coordinate system do not occur (because rod is in equilibrium of inertia and elastic forces). In stationary coordinate system, the oscillations occur with constant amplitude as the projection on the coordinate planes.

When this rod will be rotated on subcritical speed, but under the action of external axial force with frequency that is equal to critical rotational speed $145.5 \mathrm{~s}^{-1}$, the oscillation amplitude, after loss of equilibrium, will be slowly fading out (Fig. 5). Wherein, the oscillations will occur with beats of amplitude. Such beats of amplitude are the result of the periodic axial force action. Similar character of oscillation will be observed in rotation on subcritical speeds under action of periodic axial force with frequency that less than $145.5 \mathrm{~s}^{-1}$.

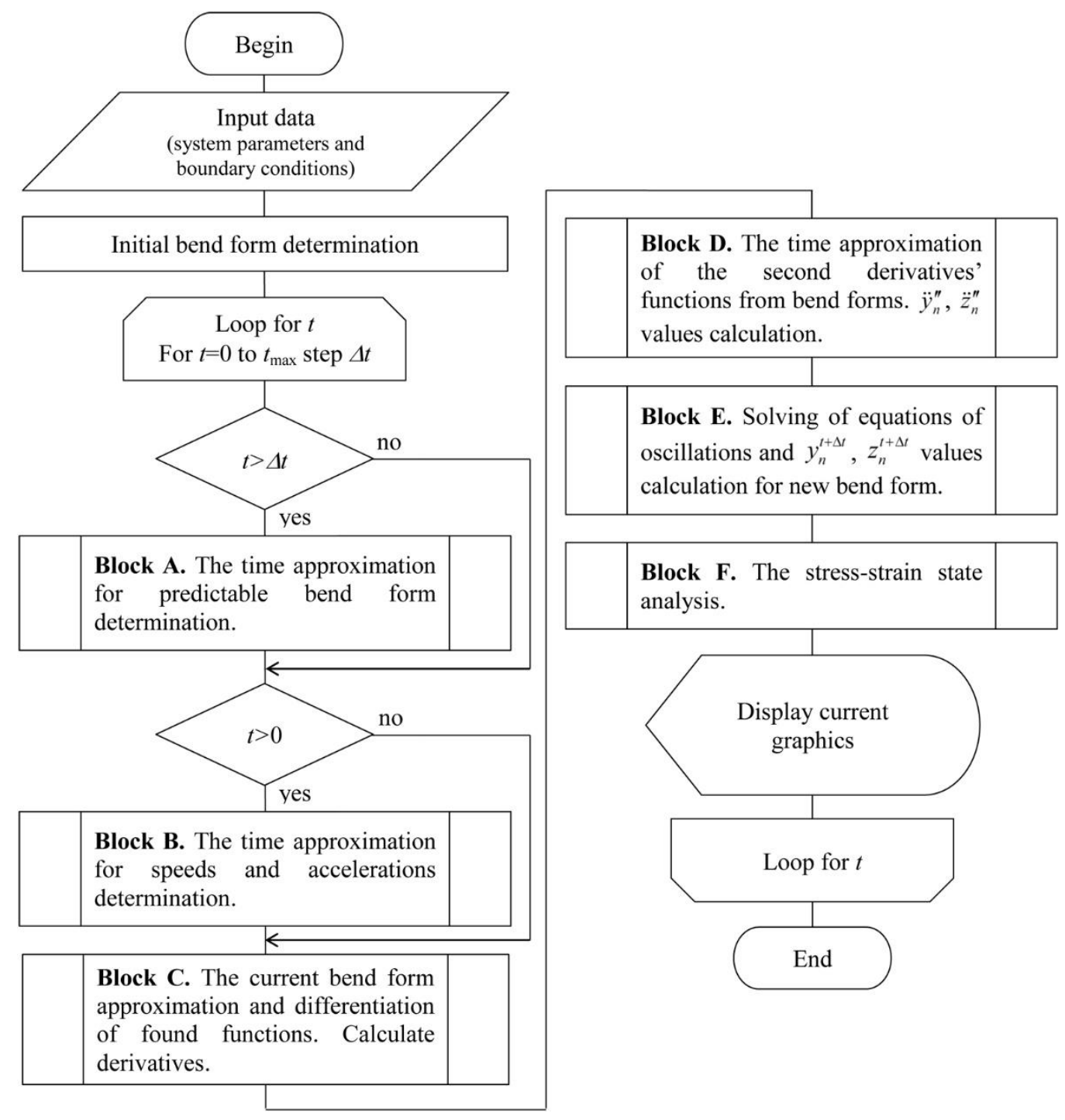

Figure 3 - The general block diagram's algorithm of the program 

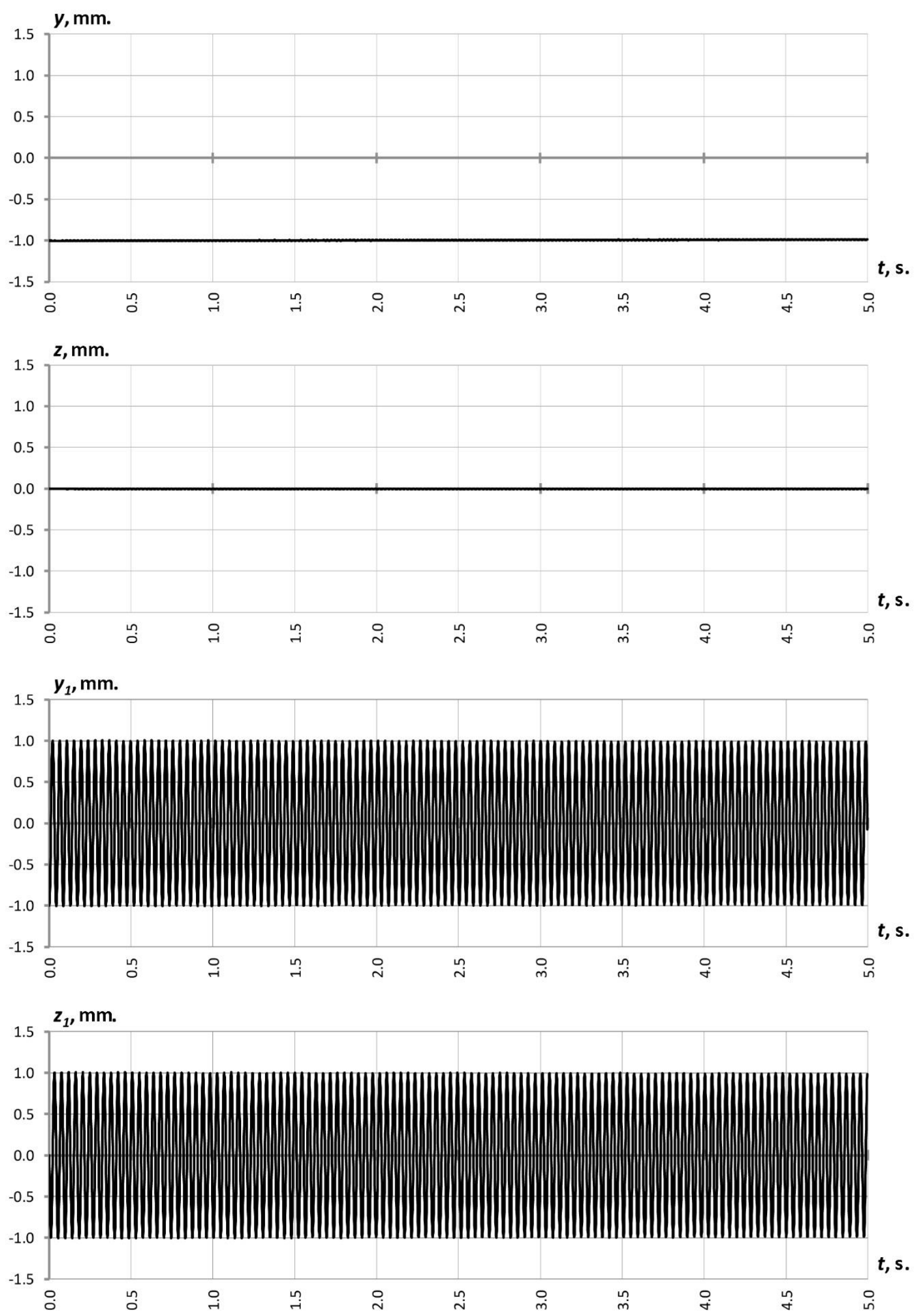

Figure 4-Oscillations of steel rod that is rotated on speed equal 145,5 $\mathrm{s}^{-1}$, in rotating and stationary coordinate system 

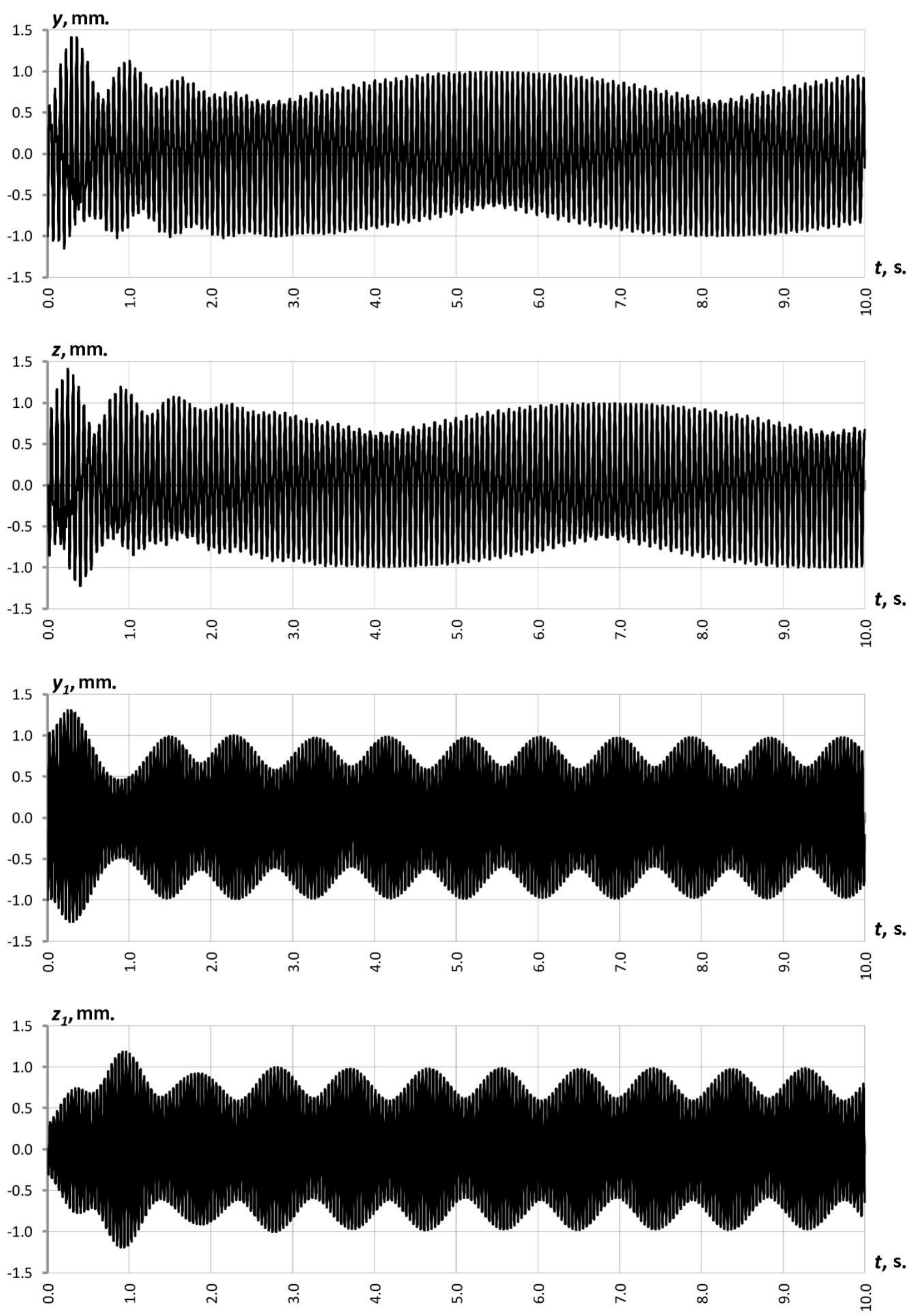

Figure 5 - Oscillations of steel rod that is rotated on speed equal $45.5 c^{-1}$, under action of the axial periodic force with frequency equal $145.5 \mathrm{~s}^{-1}$,

in rotating and stationary coordinate system 

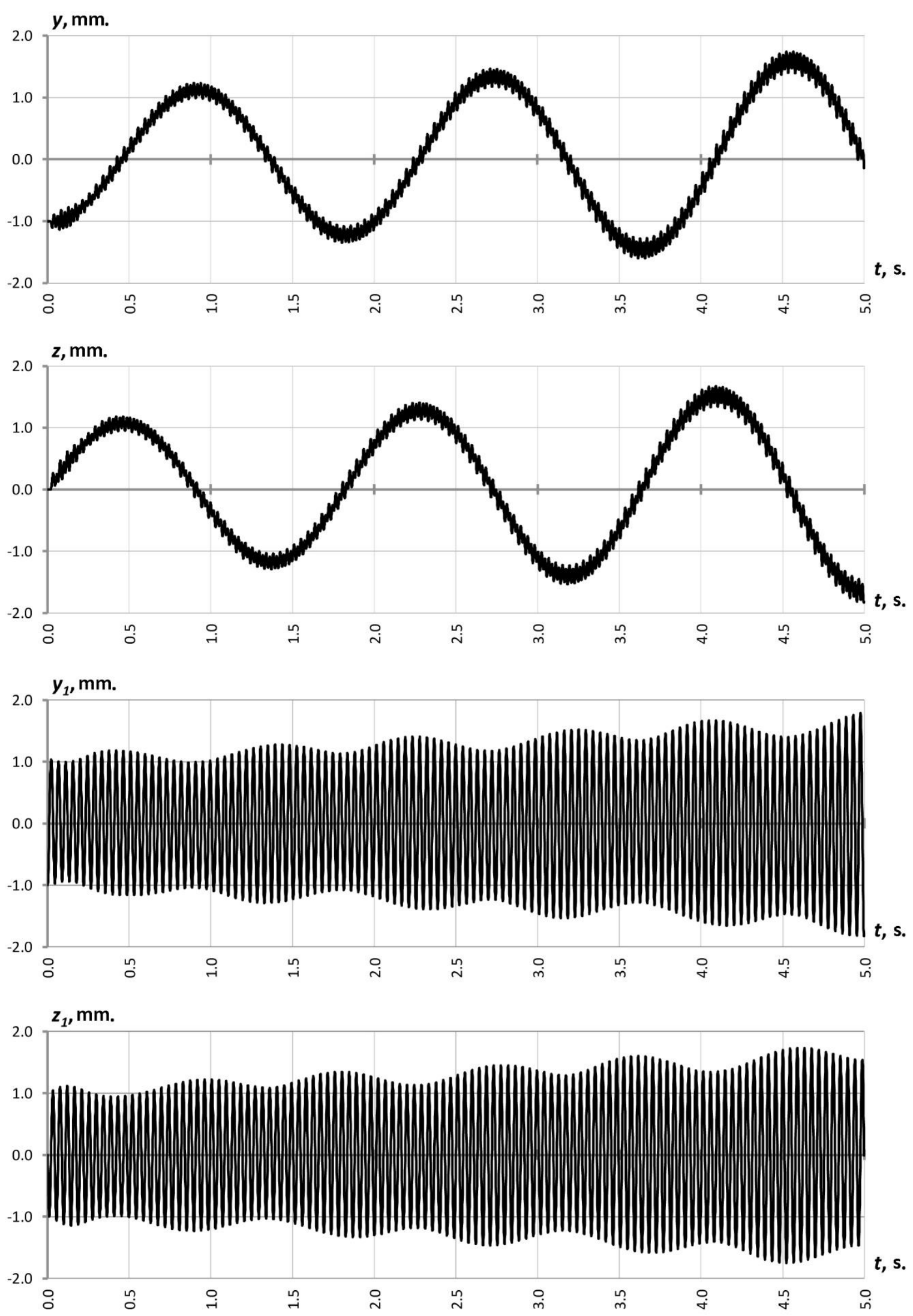

Figure 6-Oscillations of steel rod that is rotated on speed equal $145.5 \mathrm{~s}^{-1}$, under action of the axial periodic force with frequency equal $145.5 \mathrm{~s}^{-1}$,

in rotating and stationary coordinate system 


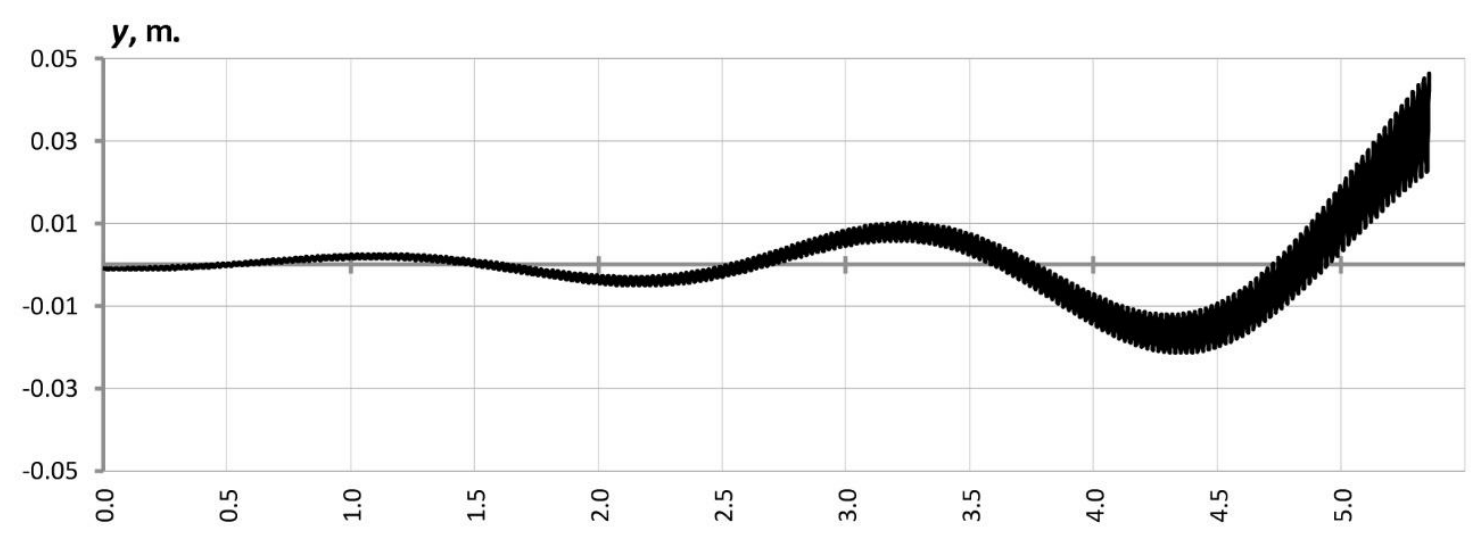

t, s.

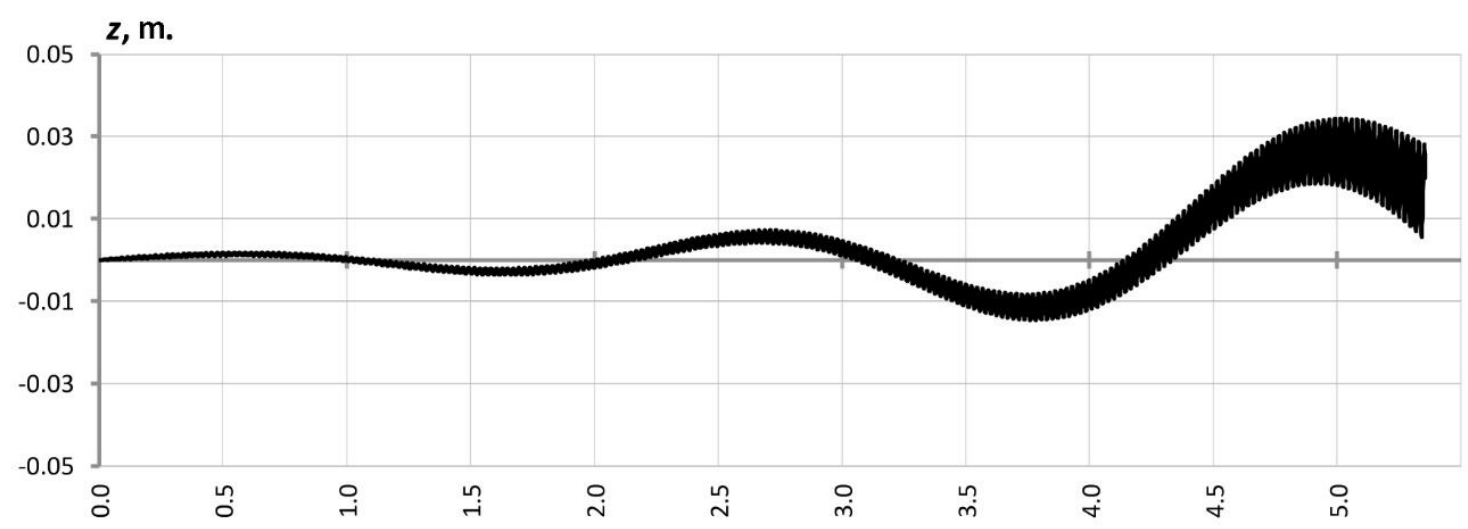

$t$, s.
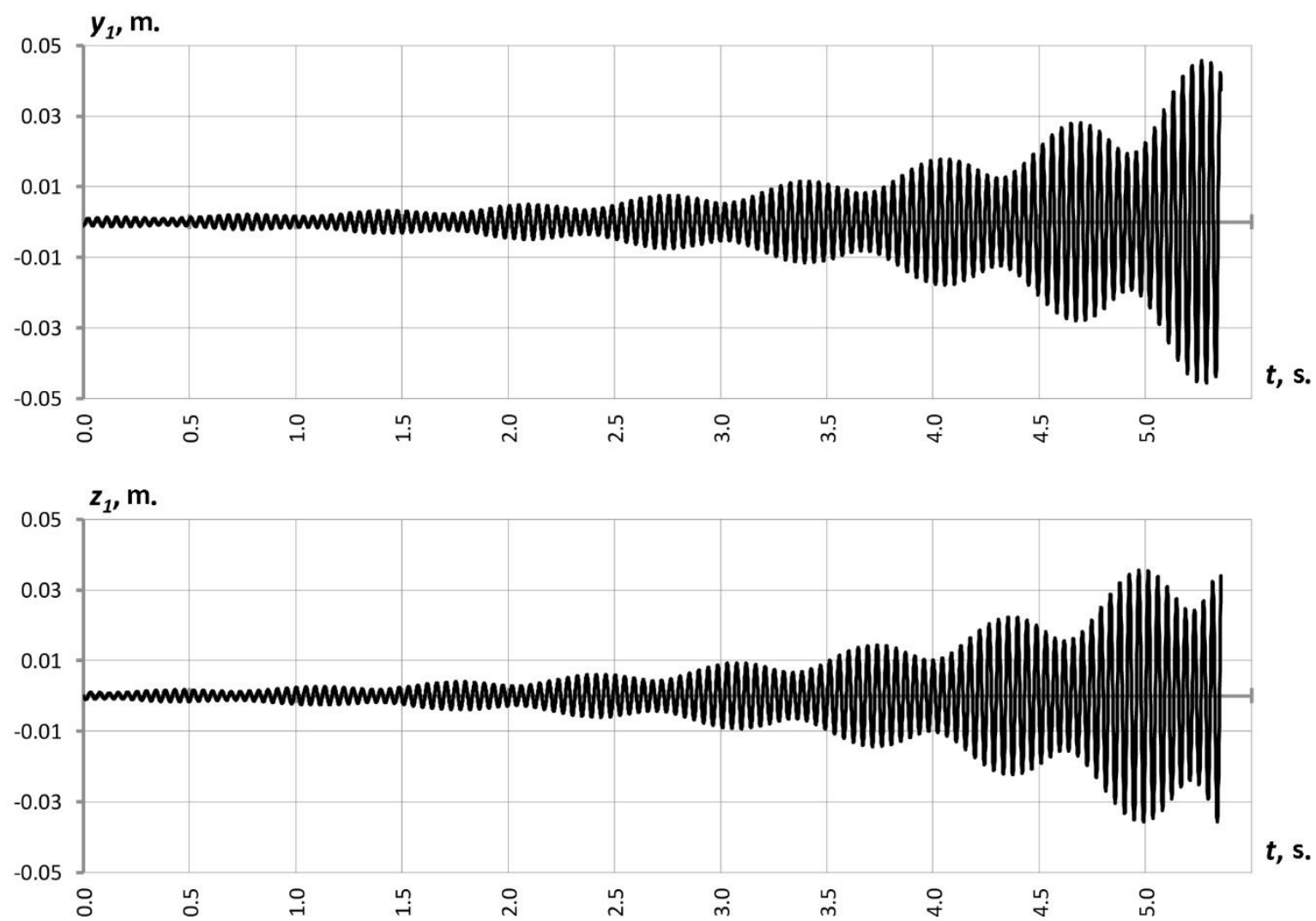

Figure 7 - Oscillations of steel rod that is rotated on speed equal $145.5 \mathrm{~s}^{-1}$, under action of the axial periodic force with frequency equal $275.5 \mathrm{~s}^{-1}$,

in rotating and stationary coordinate system 
When this rod will be rotated on critical speed 145.5 $\mathrm{s}^{-1}$, under the action of external axial force with frequency that is equal to critical rotational speed $145.5 \mathrm{~s}^{-1}$, the oscillation amplitude, after loss of equilibrium, will be rising to critical over the time (Fig. 6). Also, the oscillations will occur with beats of amplitude as result of the periodic axial force action. Similar character of oscillation will be observed in rotation on overcritical speeds under action of periodic axial force with various frequencies.

When this rod will be rotated on critical speed 145.5 $\mathrm{s}^{-1}$, but under the action of external axial force with frequency that is over then $145.5 \mathrm{~s}^{-1}$, the oscillation amplitude, after loss of equilibrium, will be rising to critical swiftly (Fig. 7).

\section{Conclusion}

Studies of the transverse oscillations of rotating elastic rods under the action of periodic axial forces indicate the influence of it on the nature of oscillatory motion. Depending on the rotational speed and beat frequencies the oscillatory motion of the rods occurs with different character of behavior. On certain speeds with different beat frequencies of axial load the oscillations have definite periodicity. The oscillations will occur with beats of amplitude. These are the result of the periodic axial force action.

\title{
References
}

1. Bakhvalov, N. S., Judkov, N. P., Kobelkov, G. M. (2015). Numerical methods. Moscow: BINOM, Laboratory of Knowledge, 639. [In Russian]

2. Bolotin, V. V. (1956). The dynamic stability of elastic systems. Moscow: Technical and Theoretical Literature Press, 600. [In Russian]

3. Dimentberg, F. M. (1959). Flexural vibrations of rotating shafts. Moscow: Publishing of AS USSR, 247.

4. Karpenko, T. N., Muzyka, I. N. (2018). Determination of natural frequencies of bending vibrations of rotating shafts. Science and production, 18, 69-78. [In Russian]

5. Munitsyn, A. I. (2008). Space bending oscillations of a rod rotating around its axis. Mathematical and computer modeling of machines and systems, 64-67. [In Russian]

6. Murtazin, I. R., Lukin, A. V., Popov, I. A. (2019). Research of flexural vibrations of rotating shafts with distributed inertial, elastic and eccentricity properties. Scientific and Technical Journal of Information Technologies, Mechanics and Optics, 19, 4, 756-766. [In Russian]. doi: 10.17586/2226-1494-2019-19-4-756-766

7. Nedin, V. O. (2020). The parametric oscillations of rotating rods under action of the axial beat load. Strength of materials and theory of structures, 104, 309-320.

8. Nedin, V. (2020). Numerical differentiation of complex bend forms of long rotating rods. Management of Development of Complex Systems, 43, 110-115. [in Ukrainian]

9. Tondl, A. (1971). The rotor dynamics of turbines. Leningrad: Energy, 297. [In Russian]

10. Petyt, Maurice. (1990) Introduction to Finite Element Vibration Analysis. Cambridge University Press, 558.

Received 14.10.2020

\author{
Лізунов Петро Петрович \\ Доктор технічних наук, професор, завідувач кафедри основ інформатики, orcid.org/0000-0003-2924-3025 \\ Київський національний університет будівництва і архітектури, Київ \\ Недін Валентин Олегович \\ Асистент кафедри основ інформатики, orcid.org/0000-0003-3138-2892 \\ Київський начіональний університет будівництва і архітектури, Київ

\section{ПАРАМЕТРИЧНІ КОЛИВАННЯ ПРУЖНИХ СТРИЖНІВ, ЩО ОБЕРТАЮТЬСЯ, ПІД ДІЄЮ ПЕРІОДИЧНИХ ПОЗДОВЖНІХ СИЛ}

\footnotetext{
Анотація. Представлено результати чисельного дослідження впливу дії періодичної поздовжньої сили на поперечні коливання довгих стрижсів, щьо обертаються. Коливальний рух розглянуто в просторі з урахуванням дї гіроскопічних сил та геометричної нелінійності стрижня. Дослідження здійснені за допомогою комп ютерної програми з графічним інтерфейсом, що розроблена авторами. Описано прочес чисельного розв'язання рівнянь коливального руху 3 використанням методики чисельного диференціювання за допомогою поліноміальних сплайн-функиій $і$ методу чисельного інтегрування за часом Хубболта. Викладено загальну блок-схему алгоритму, який описує процес багатократного (циклічного) розв'язку системи рівнянь коливального руху для кожної точки системи з метою пошуку нових координат положення ичих точок в кожний наступний момент часу $t+\Delta t$. Комп'ютерна програма, в якій реалізовано наведений алгоритм, дає змогу спостерігати за поведінкою рухомої комп 'ютерної моделі, яка демонструє прочес коливального руху при обертанні, а також будувати графіки коливального руху, графіки зміни швидкостей і прискорень в різних системах
} 
координат. Використовуючи зазначену програму, здійснено дослідження динаміки низки об'єктів, робочі органи яких моделюються довгомірними пружними стрижнями. Для досліджуваних об'єктів показано, що на різних швидкостях обертання $i$ частотах дї ударного поздовжнього навантаження коливальний рух відбувається з неоднаковою поведінкою. На певних швидкостях з різною частотою дії осьового навантаження коливання мають встановлену періодичність і виникають із биттям, щяо є результатом дії періодичної осьової сили.

Ключові слова: стрижні; поперечні коливання; чисельне диференціювання; форми вигину; гіроскопічні сили

\title{
Лизунов Пётр Петрович
}

Доктор технических наук, профессор, заведующий кафедрой основ информатики, orcid.org/0000-0003-2924-3025

Киевский национальный университет строительства и архитектуры, Киев

Недин Валентин Олегович

Ассистент кафедры основ информатики, orcid.org/0000-0003-3138-2892

Киевский национальный университет строительства и архитектуры, Киев

\section{ПАРАМЕТРИЧЕСКИЕ КОЛЕБАНИЯ ВРАЩАЮЩИХСЯ УПРУГИХ СТЕРЖНЕЙ ПОД ДЕЙСТВИЕМ ПЕРИОДИЧЕСКИХ ПРОДОЛЬНЫХ СИЛ}

\begin{abstract}
Аннотация. Представлены результаты численного исследования влияния действия периодической продольной силы на поперечные колебания длинных вращающихся стержней. Колебательное движение рассмотрено в пространстве с учетом действия гироскопических сил и геометрической нелинейности стержня. Исследования проведены с помощью компьютерной программы с графическим интерфейсом, которая была разработана авторами. Описан процесс численного решения уравнений колебательного движения с использованием методики численного дифференцирования с помощью полиномиальных сплайн-функиий и метода численного интегрирования по времени Хубболта. Показана общая блок-схема алгоритма, который описывает процесс многократного (ииклического) решения системы уравнений колебательного движения для каждой точки системы с целью поиска новых координат положения этих точек в каждый последующий момент времени $t+\Delta t$. Компьютерная программа, в которой реализован представленный алгоритм, позволяет наблюдать за поведением компьютерной модели, демонстрирующей проиесс колебательного движения во вращательном движении, а также строить графики колебаний, графики изменения скоростей и ускорений в разных системах координат. Используя указанную программу, выполнено исследование динамики объектов, рабочие органы которых моделируются длинномерными упругими стержнями. Для исследуемых объектов показано, что на различных скоростях вращения и частотах действия ударной продольной нагрузки колебательное движение происходит с разным характером поведения. На определенных скоростях с разной частотой действия осевой нагрузки колебания имеют установленную периодичность и возникают с биениями, которые являются результатом действия периодической осевой сильь.
\end{abstract}

Ключевые слова: вращающиеся стержни; поперечные колебания; численное дифференцирование; формы изгиба; гироскопические силь

\section{Link to the article}

APA Lizunov, Petro \& Nedin, Valentyn. (2020). The parametric oscillations of rotating elastic rods under the action of the periodic axial forces. Management of Development of Complex Systems, 44, 56-64, dx.doi.org \10.32347/24129933.2020.44.56-64.

ДСТУ Лізунов П. П., Недін В. О. Параметричні коливання пружних стрижнів, що обертаються, під дією періодичних поздовжніх сил. Управління розвитком складних систем. Київ, 2020. № 44. С. 56 - 64, dx.doi.org\10.32347/24129933.2020.44.56-64. 